УдК 339.9

O. A. Аон,

старший викладач кафедри економіки та управління начіональним господарством, Аніпровський начіональний університет імені Олеся Гончара, м. Аніпро

ORCID ID: 0000-0003-1062-1671

DOI: $10.32702 / 2306-6814.2020 .21-22.91$

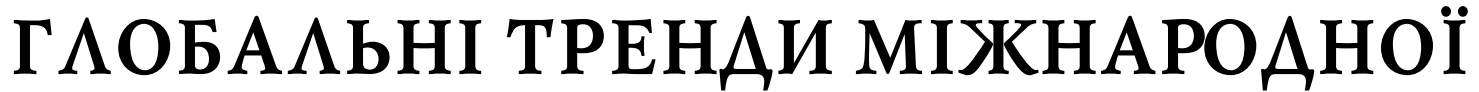 ТРУАОВОЇ МІГРАЦІї
}

O. Don,

Senior lecturer of the Department of Economics and Management of National Economy Oles Honchar Dnipro

National University, Dnipro

\section{GLOBAL TRENDS OF INTERNATIONAL LABOR MIGRATION}

Доведено, що на початку XXI ст. міжнародна трудова міграція перетворилася на потужну силу, яка сприяє економічним, соціальним, культурним перетворенням у глобальному просторі. У сьогоднішньому, все більш взаємопов язаному світі, міжнародна міграція є об'єктивною реальністю, яка торкається майже усіх країн світового господарства. Люди рухаються у пошуках роботи, освіти і покращення якості життя. Водночас конфлікти, бідність, нерівність і відсутність коштів для комфортного життя примушують людей, залишати їх будинки з метою пошуків кращого майбутнього для себе і своїх родин за кордоном. Досліджено динаміку сучасних людських переміщень між країнами та регіонами світу, які стали набагато швидкими, легкими, дешевшими, ніж парудесятків років назад. Проаналізовані ключові індикатори стосовно якісних характеристик мігрантів та їх розподіл за групами країн та сферами економічної діяльності. Встановлено, що переважна більшість трудових мігрантів, понад 80\% яких знаходиться у працездатному віці, рухається до економічно розвинених країн з високим рівнемдоходів і цей потік постійно зростає. Виявлені глобальні труднощі у сфері міжнародної трудової міграції та розглянуті програми для країн з координації міграційних потоків.

It is proved that at the beginning of the XXI century international labor migration has become a powerful force that contributes to economic, social and cultural transformation in the global space. In today's increasingly interconnected world, international migration is an objective reality that affects almost all countries in the world economy. People are moving in search of work, education and improving their quality of life. At the same time, conflicts, poverty, inequality and lack of funds for a comfortable life force people to leave their homes in search of a better future for themselves and their families abroad. The dynamics of modern human movements between countries and regions of the world, which have become much faster, easier, cheaper than a couple of decades ago, has been studied. The key indicators concerning the qualitative characteristics of migrants and their distribution by groups of countries and spheres of economic activity are analyzed. It has been found that the vast majority of migrant workers, more than $80 \%$ of whom are of working age, move to economically developed countries with high incomes and this flow is constantly growing. For 20 years, the United Arab Emirates has been the country with the largest share of international migrants. Global difficulties in the field of international labor migration are identified and programs for countries to coordinate migration flows are considered.

International migration is a multidimensional reality that is of great importance for the development of countries of origin, transit and destination, which requires consistent and comprehensive responses. The complexity of international labor migration and mobility, including refugee flows, is growing. Lack of regulation of labor migration can exacerbate the deficit of decent work for migrant workers and their families, as well as lead to long-term adverse socio-economic costs for countries 
of origin and destination. Whether labor migration will be useful or not depends very much on the political base of the countries of origin and destination, as well as on bilateral, regional and multilateral cooperation between them.

Ключові слова: міжнародна міграція, трудова міграція, країни сВітового господарства, Міжнародна організація міграції, регіональна та галузева структура трудових мігрантів.

Key words: international migration, labor migration, countries of world economy, International organization of migration, regional and branch structure of labor migrants.

\section{ПОСТАНОВКА ПРОБАЕМИ}

Міграція з метою працевлаштування є однією з найважливіших глобальних проблем людства, яка охоплює більшість країн світу. Сьогодні на ринку праці діють дві основні сили, що призводять до збільшення потоків міжнародної трудової міграції - багато людей у працездатному віці не можуть знайти роботу, або не можуть знайти адекватну роботу для утримання себе та своєї родини на Батьківщині, тоді як у деяких інших країнах виникає нестача робітників у різних галузях економіки.

Інші фрактори руху людських ресурсів включають соціально-економічні та політичні кризи, демографрічн зміни та збільшення різниці у розмірах заробітної плати між розвинутими країнами і країнами, що розвиваються. Отже, через кордони відбувається значний рух людських ресурсів для працевлаштування, причому жінки мігрують на роботу в значно більшій кількості, ніж у минулі роки, і зараз складають приблизно половину всіх трудових мігрантів.

За умови реалізації виваженої та обгрунтованої політики трудова міграція може допомогти країнам реагувати на зміни у попиті та пропозиції робочої сили, стимулювати інновації та сталий розвиток, а також передавати досвід та оновлювати навички. Однак відсутність міжнародних стандартів щодо концепцій, визначень та методів для вимірювання даних про трудову міграцію все ще потребує вирішення.

\section{АНА ІІЗ ОСТ АНHIX АОС IАЖЕНН І ПУБ $\Lambda$ ІКАЦІЙ}

На глобальному рівні зростання масштабів міжнародної трудової міграції потребує ії̈ обліку, контролю та регулювання з метою підвищення рівня зайнятості та сталого економічного зростання в країнах світу. Сучасні економічні дослідження міжнародної трудової міграції характеризується різноманітністю підходів щодо тлумачення термінів, пов'язаних з міграцією робочої сили, обсягів та методів збору відповідних статистичних даних. Ці відмінності представляють деякі труднощі для проведення порівняльного аналізу взаємозв'язків між трудовою міграцією і зайнятістю в країнах світового господарства та його регіонах. Значна частина даних корисна для встановлення тенденцій, але не забезпечує достатньої основи для поглибленого соціально-економічного аналізу трудової міграції.

Тому для досягнення цілі даного дослідження були проаналізовані ключові показники динаміки міжнародної міграції у глобальному вимірі та регіональні й галузеві потоки трудової міграції.
Попри численні публікації, які з'явилися в останні роки, поки що не сорормовано цілісну систему про механізми регулювання трудової міграції, а особливо в період глобальної інтеграції міждержавних ринків праці. Недостатньо досліджено теоретико-методологічний та методичний апарат оцінки та аналізу трудової міграції, ії̈ регіональної, галузевої та статево-вікової специфіки та міграційних установок, потребує вдосконалення комплексне вивчення підходів з питань регулювання трудової міграції тощо.

\section{META CTATTI}

Метою статті $€$ виявлення глобальних трендів міжнародної трудової міграції на основі дослідження іiї основних показників у світовому вимірі.

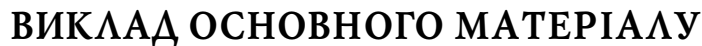 АОС $А$ АЖЕННЯ}

Однією з найбільш складних форм системи міжнародних економічних відносин $€$ міжнародна трудова міграція, яка $€$ важливою складовою світового ринку праці, підсистему міждержавних потоків робочої сили різних професій, рівнів компетенцій, які зайняті в різноманітних сорерах та галузях світової економіки.

Водночас Гуменюк Ю. розглядає міграцію робочої сили як "переселення працездатного населення з одних держав в інші терміном більш ніж на рік, викликане причинами економічного й іншого характеру" [1].

Таблиця 1. Ключові показники міжнародної міграції у глобальному вимірі

\begin{tabular}{|c|c|c|c|}
\hline № & Показники міжнародної міграції & $2000 \mathrm{p}$. & 2019 p. \\
\hline 1 & $\begin{array}{l}\text { Загальна чисельність міжнародних мігрантів } \\
\text { у світі, млн ос. }\end{array}$ & 173,5 & 271,6 \\
\hline 2 & $\begin{array}{l}\text { Частка міжнародних мігрантів у загальній } \\
\text { чисельності населення світу, \% }\end{array}$ & 2.8 & 3.5 \\
\hline 3 & $\begin{array}{l}\text { Частка жінок у загальній чисельності } \\
\text { міжнародних мігрантів, \% }\end{array}$ & 47.5 & 47.9 \\
\hline 4 & $\begin{array}{l}\text { Частка дітей 0-14 років у загальній } \\
\text { чисельності міжнародних мігрантів, \% }\end{array}$ & 16.0 & 13.9 \\
\hline 5 & $\begin{array}{l}\text { Регіон } 3 \text { найбільшою часткою міжнародних } \\
\text { мігрантів, \% }\end{array}$ & $\begin{array}{l}\text { Океанія } \\
(17,1)\end{array}$ & $\begin{array}{l}\text { Океанія } \\
(21,1)\end{array}$ \\
\hline 6 & $\begin{array}{l}\text { Країна з найбільшою часткою міжнародних } \\
\text { мігрантів }\end{array}$ & OAE & OAE \\
\hline 7 & $\begin{array}{l}\text { Загальна чисельність трудових мігрантів, } \\
\text { млн осіб }\end{array}$ & - & 164 \\
\hline 8 & $\begin{array}{l}\text { Глобальні міжнародні грошові перекази, } \\
\text { млрд дол. США }\end{array}$ & 126 & 689 \\
\hline 9 & Кількість біженців, млн ос. & 14 & 25.9 \\
\hline 10 & $\begin{array}{l}\text { Кількість держав-членів Міжнародної } \\
\text { організації міграції }\end{array}$ & 76 & 173 \\
\hline 11 & $\begin{array}{l}\text { Кількість виїзних офісів Міжнародної } \\
\text { організації міграції, од. }\end{array}$ & 120 & 436 \\
\hline
\end{tabular}

Джерело: [4]. 
Таблиця 2. Динаміка чисельності міжнародних мігрантів за регіонами світу, млн осіб

\begin{tabular}{|l|l|l|l|l|l|}
\hline Регіони світу & \multicolumn{1}{|c|}{2000 p. } & \multicolumn{1}{c|}{2005 p. } & \multicolumn{1}{c|}{2010 p. } & \multicolumn{1}{c|}{2015 p. } & \multicolumn{1}{c|}{2019} \\
\hline Весь світ & 173588441 & 191615574 & 220781909 & 248861296 & 271642105 \\
\hline Африка & 15051677 & 15969835 & 17804198 & 23476251 & 26529334 \\
\hline Азія & 49394322 & 53439306 & 65938712 & 77231760 & 83559197 \\
\hline Свропа & 56858788 & 63594822 & 70678025 & 75008219 & 82304539 \\
\hline $\begin{array}{l}\text { Південна } \\
\text { Америка }\end{array}$ & 6570729 & 7224942 & 8262433 & 9441679 & 11673288 \\
\hline $\begin{array}{l}\text { Північна } \\
\text { Америка }\end{array}$ & 40351694 & 45363257 & 50970861 & 55633443 & 58647822 \\
\hline Океанія & 5361231 & 6023412 & 7127680 & 8069944 & 8927925 \\
\hline
\end{tabular}

Джерело: [5].

Таблиця 3. Топ-10 країн світу, до яких прямують міжнародні мігранти, млн осіб

\begin{tabular}{|l|l|l|l|l|}
\hline \multirow{2}{*}{ Країни } & \multicolumn{2}{|c|}{$\begin{array}{c}\text { Кількість } \\
\text { міжнародних } \\
\text { мігрантів, млн ос. }\end{array}$} & $\begin{array}{c}\text { Абсолютний } \\
\text { приріст, } \\
\text { млн ос. }\end{array}$ & $\begin{array}{l}\text { Відносний } \\
\text { приріст, \% }\end{array}$ \\
\cline { 2 - 3 } & \multicolumn{1}{|c|}{2000 р. } & \multicolumn{1}{|c|}{2019 р. } & & \\
\hline США & 34,8 & 50,7 & 15,9 & 45,7 \\
\hline Канада & 5,5 & 7,9 & 2,4 & 28,9 \\
\hline Німеччина & 8,9 & 13,1 & 4,2 & 47,1 \\
\hline Франція & 6,3 & 8,3 & 2,0 & 31,7 \\
\hline Великобританія & 4,7 & 9,5 & 4,8 & 102,1 \\
\hline Італія & 2,1 & 6,2 & 4,1 & 295,2 \\
\hline Російська Федерація & 11,9 & 11,4 & $-0,5$ & $-4,2 \%$ \\
\hline $\begin{array}{l}\text { Об'єднані Арабські } \\
\text { Емірати }\end{array}$ & 2,4 & 8,5 & 6,1 & 354,1 \\
\hline Саудівська Аравія & 5,2 & 13,1 & 7,9 & 251,9 \\
\hline Австралія & 5,3 & 8,9 & 3,6 & 67,9 \\
\hline
\end{tabular}

Джерело: [4].

Важливо відзначити різницю між визначенням іноземного працівника-мігранта та міжнародного мігранта. Сьогодні не існує загально визнаного міжнародного поняття трудової міграції. Але її головними суб'єктами виступають працівники-мігранти, яких Міжнародна організація праці (МОП) визначає як: "Вся сукупність міжнародних мігрантів, які зараз працюють або не працюють і шукають роботу в країні свого проживання" [8]. Статистичний відділ ООН, дає таке визначення іноземного працівника-мігранта: "Іноземці, які приймаються державою перебування з конкретною метою здійснення економічної діяльності, які отримують винагороду в

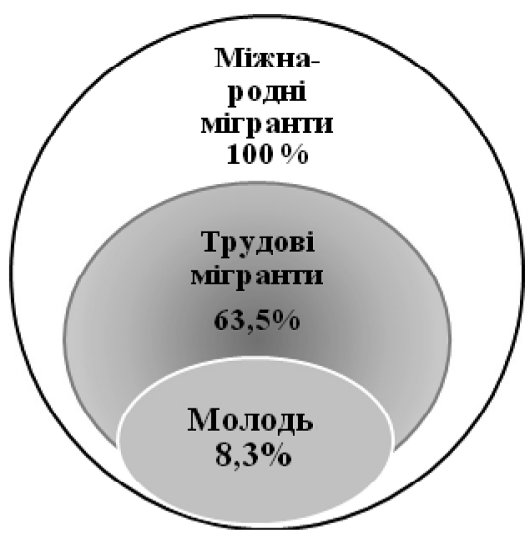

Рис. 1. Частка трудових мігрантів (у тому числі молодого віку) у загальній чисельності міжнародних мігрантів у 2017 році

Джерело: [5]. межах країни перебування. Тривалість перебування, як правило, обмежена, як і тип роботи, яку вони можуть виконувати. Їх утриманці також відносяться до цієї категорії" [5]. 3 іншого боку, працівники-мігранти часто $€$ також міжнародними мігрантами.

Трудова міграція отримала новий поштовх завдяки Декларації Діалогу на високому рівні Генеральної Асамблеї ООН з питань міжнародної міграції та розвитку у жовтні 2013 р., яка визнала мобільність людини ключовим фактором сталого розвитку та важливий внесок трудової міграції у реалізацію Цілей розвитку тисячоліття. На міжнародній конференції праці 2014 р. Генеральний директор МОП закликав "побудувати порядок денний для справедливої міжнародної міграції, який не лише поважає основні права трудових мігрантів, але й відкриває реальні можливості для гідної праці" [7]. Це означає справедливий розподіл благ, які вони допомагають створювати, та необхідність фрормування та реалізації міграційних програм, що відповідають рівноцінним інтересам країн походження та призначення, робітників-мігрантів, роботодавців та громадян.

На думку Сардака С.Е., "міжнародних трудових мігрантів здебільшого приваблюють вищі (іноді кілька разів) заробітні плати у порівнянні з країнами походження. Також важливим мотивом є підвищений попит на певні спеціальності, що в свою чергу, передбачає більш високий заробіток мігрантів" [3]. В таблиці 1 відображені ключові показники міжнародної міграції в світі, які були представлені в авторитетному міжнародному виданні "World Migration Report 2020" [4].

Як бачимо з показників, що наведені в таблиці 1, у перші майже два десятка років XXI ст., міграційні процеси відбувалися дуже активно, про що свідчать значення їх ключових показників. Так, загальний приріст числа міжнародних мігрантів становив майже 100 млн осіб. Якщо у 2000 р. міжнародних мігрантів в світі налічувалось більш 173 млн ос., то у 2019 р.- майже 272 млн ос. Глобальні грошові перекази зросли майже у 5,5 разів - зі 126 млрд дол. у 2000 р. до 689 млрд дол. в 2019 р. За 20 років збільшилась кількість країнучасниць Міжнародної організації міграції зі 76 до 173 та кількість її виїзних офрісів зі 120 до 436 од. Всі ці факти у сукупності свідчать про те, що на початку XXI ст. під впливом політичних, соціально-економічних, демографрічних та ін. фракторів відбувається значне прискорення міграційних процесів у країнах світової спільноти.

У таблиці 2 представлена динаміка чисельності міжнародних мігрантів та їх розподіл за регіонами світу.

За даними таблиці 2, можна констатувати, що за останні 20 років відбулося збільшення чисельності міжнародних мігрантів у світі майже на 100 млн ос., або більш ніж на 50 \%. Це явище можна охарактеризувати як позитивний динамічний процес, який охопив всі регіони світу та загалом глобальну економіку. Так, у 2019 р. з 272 млн мігрантів, майже 1/3, мігрувала до країн Азії 83,5 млн осіб, до європейських країн було переміщено 82,3 млн осіб, доПівнічної Америки - 58,6 млн ос., до країн 
Асррики - 26,5 млн ос., до Південної Америки - 11,6 млн ос., в Океанію майже 9 млн ос. Це відповідно на 34,1 млн ос., 25,4 млнос., 18,3 млн ос., 11,5 млн ос., 5,1 млн ос., 3,7 млн ос. більше ніж у 2000 році.

Таблиця 3 містить інфрормацію стосовно країн, які $€$ дуже привабливими для мігрантів в останні майже два десятка років.

За даними, що наведені у таблиці 3, можна зробити висновок, що кількість міжнародних мігрантів у країнах має стійку тенденцію до збільшення, особливо швидка динаміка такого зростання зафіксована в США + 15,9 млн ос., Саудівській Аравії + 7,9 млн ос., Об'єднаних Арабських Еміратах +6, 1 млн ос. Серед європейських країн найбільше зростання мігрантів відбувалось у Великій Британії + 4,8 млн ос., Німеччині + 4,2 млн ос. та Італії $+4,1$ млн ос. На це вплинули як процеси глобалізації світового господарства, так і поглиблення регіональних інтеграційних процесів. Лише у Російський Федерації за цей період відбулося скорочення числа мігрантів на 500 тис. осіб, що частково пов'язано із переорієнтацію українських заробітчан на ринки праці країн ЄС.

За підрахунками МОП у світі налічується $164 \mathrm{Mлн}$ робітників-мігрантів що дорівнювало 63,5 \% від усієї кількості мігрантів (рис. 1). Ці працівники вносять прямий і опосередкований вклад у розвиток суспільства та економіки країн, що їх приймають. Однак у багатьох країнах мігранти відчувають деякі труднощі на ринку праці через обмеження права на працю, невизнання їх іноземних повноважень та досвіду роботи, дискримінацію та мовні бар'єри та інші фрактори.

Чоловіки складають більшу частку трудових мігрантів. Так, у 2017 роцічоловіків-мігрантів налічувалось 95,7 млн ос., а чисельність жінок-мігрантів дорівнювала 68,1 млн ос., або 58,4 і 41,6 \%, відповідно (рис. 2). Більша частка чоловіків серед трудових мігрантів пояснюється їх більшою кількістю серед міжнародних мігрантів працездатного віку (54,2 \% порівняно з 2013 роком, 45,8 \% для жінок) та їх вищу продуктивність праці (75,5 \% проти 63,5 \% відповідно). Більше того, між 2013 та 2017 роками частка чоловіків серед робітників-мігрантів збільшилася з 55,7\% до 58,4 відсотка, частка чоловіків серед мігрантів працездатного віку зросла з 51,9 \% у 2013 році до 54,2 \% у 2017 році, частка жінок серед мігрантів робітники впала з 44,3 до 41,6 \% протягом того ж часового періоду. Більш висока частка чоловіків серед трудових мігрантів може пояснюватися також такими факторами, включаючи більшу ймовірність міграції жінок з інших причин ніж зайнятість (наприклад, для возз'єднання сім'ї), а також можливою дискримінацією жінок, що зменшує їхні можливості працевлаштування в зазначених країнах. Соціальна стигматизація, дискримінаційний вплив політики та законодавства, насильство та цькування не тільки підриває доступ жінок до гідної роботи, але також може призвести до відсутності рівної оплати праці та спад розвитку секторів, що більш опановані жінками.

Глобальний розподіл робітників-мігрантів за галузями економічної діяльності та за статтю відображено у таблиці 4.

Як свідчать дані, наведені у таблиці 4, переважна більшість трудових мігрантів у світі були зайняті у сфрері послуг - 106,8 млн ос. зі 150,3 млн робітників-мігрантів, що складає 71,1\%. Зайнятість у промисловості, включаючи обробну і будівництво, становила 26,7 млн осіб $(17,8 \%)$ та у сільському господарстві 16,7 млн осіб $(11,1 \%)$. Серед 71,1\% трудових мігрантів, які зайняті у в секторі послуг, близько 7,7 \% працювали як побутові працівників та 63,4\% в інших сорерах послуг. Цікаво відзначити відмінності між чоловічим та жіночим розподілом робітників-мігрантів за секторами. Для обох статей, на сільське господарство припадало майже однаково (близько 11\%). Чоловіки більше зайняті у промисловості, ніж жінки (19,8 \% проти 15,3 \%) та менше у сорері послуг $(69,1 \%$ проти $73,7 \%)$.

Як бачимо з рисунка 2, вікові склади чоловічої та жіночої статей трудових мігрантів дуже схожі. Загалом зі 164 млн трудових мігрантів 141,7 млн (86,5 \%) складали працездатні особи у віці 25-64 років. Частка молоді у віці 15-24 років становила 8,3\%, а питома вага осіб віком більш 65 років була 5,2 \% із загального числа трудових мігрантів. 


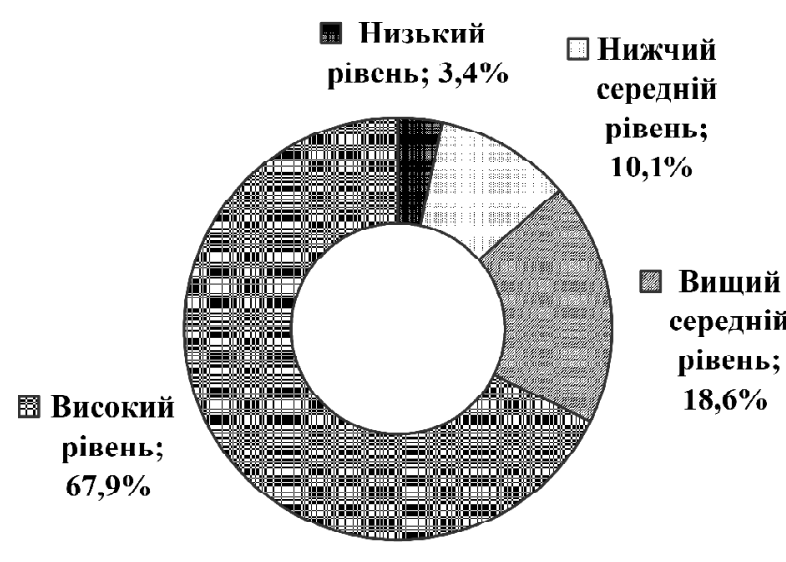

Рис. 3. Робітники-мігранти в країнах з різним рівнем доходів, 2017 р.

Джерело: [8].

Дорослі старшого віку більш здатні мігрувати до іноземних країн і виграють більше, ніж молодші особи, які мають менше досвіду, але у мігрантів старшого віку залишилися менш економічно активних років. Особи, як правило, рухаються у свої найпродуктивніші роки, що $є$ великою перевагою і для країн призначення, а також для і країн походження з точки зору грошових переказів. Справа в тому, що переважна більшість трудових мігрантів складається з дорослих людей старшого віку, а те, що деякі країни походження втрачають частину своєї робочої сили, може мати негативні наслідки для їх економічного зростання. Важливо зазначити, що еміграція саме осіб молодшого віку може забезпечити джерело грошових переказів для країн походження.

3164 мільйонів трудових мігрантів у всьому світі 111,2 мільйона $(67,9 \%)$ працюютьу країнах з високим рівнем доходу, 30,5 мільйона $(18,6 \%)$ у країнах з вищим середнім рівнем доходу, 16,6 мільйонів $(10,1$ відсотка) у країнах із нижчим середнім рівнем доходу та 5,6 млн $(3,4 \%)$ у країнах із низьким рівнем доходу (рис. 3).

Для громадян Європейського Союзу свобода пересування і вибору місця проживання означає, що працівники мають право вільно рухатися в межах країн-членів ЄС, шукати роботу і працевлаштовуватися на таких самих умовах, що пропонуються громадянам тієї чи іншої держави-члена ЄС (із деякими обмеженнями). Ці правила не поширюються на громадян держав, що не належать до ЄС. Мобільність робочої сили стає питанням міграційної політики країн. 3 метою попередження неврегульованої, нелегальної міграції, експлуатації і "втрати мізків" деякі держави-члени ЄС у співпраці із державами походження мігрантів запровадили програми обміну інформацією. Управління ринком праці, на якому задіяні 490 млн осіб (із них працездатне населення становить більше 238 млн), вимагає особливих ме-

Джерело: [8]. ханізмів і інструментів. Для заповнення вакансій відповідними працівниками у 1993 р. Європейською Комісією була створена партнерська мережа національних служб зайнятості держав-членів ЄС, а також Норвегії, Ісландії, Ліхтенштейну, Швейцарії та інших партнерських організацій - EURES.

Як бачимо, 60,8\% усіх трудових мігрантів сконцентровано у регіонах: Північна, Південна та Західна Європа $(23,9 \%)$, Америка $(23,0 \%)$, та Арабські країни $(13,9 \%)$. Іншими регіонами, серед яких $€$ незначна кількість працівників-мігрантів (понад 5 \%), є Східна Європа, Африка на південь від Сахари, Південно-Східна Азія та Тихий океан, а також Центральна та Західна Азія. Найменша кількість трудових мігрантів знаходиться у Північній Афрриці (менш $1 \%$ ).

\section{ВИСНОВКИ}

У підсумку можна зазначити, що загалом мігранти стикаються з труднощами у забезпеченні роботи, доступу до профресій, що відповідають їх освітньому рівню, та отримання належного заробітку. Відсутність визнання кваліфікації та досвіду, низький рівень володіння мовою та дискримінація можуть зіграти свою роль у цьому. Проте у кількох країнах із ефективною міграційною політикою чи особливими потребами на ринку праці вони можуть знайти належну роботу з гідною заробітною платою. Не все ще відомо про мільйони трудових мігрантів по всьому світу. Потрібні більш вичерпні дані про їх умови праці, які в свою чергу можуть підтримувати більш цілеспрямовану політику, спрямовану на захист прав та забезпечення гідної роботи для всіх, незалежно від статусу мігрантів.

Оскільки міграція робочої сили є транскордонним явищем, посилення національних, субрегіональних та регіональних механізмів соціального діалогу, процесів та інституцій з питань трудової міграції має бути ключовою особливістю роботи МОП і вимагає тісної співпраці з Регіональними економічними комісіями ООН та регіо-

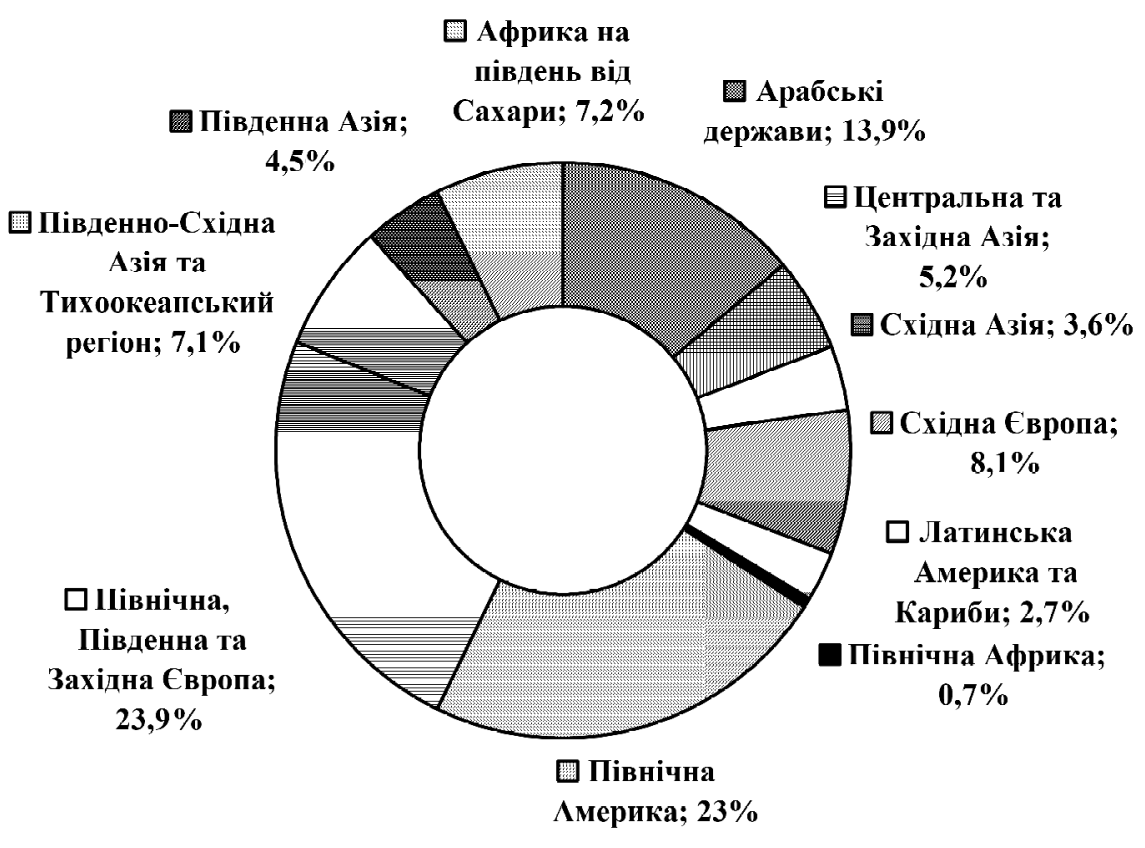

Рис. 4. Розподіл трудових мігрантів за регіонами світу у 2017 p. 
нальними економічними спільнотами (PEC). Для успішного вирішення труднощів у сорері міжнародної трудової міграції, експерти МОП розробили та запропонували міграційну програму для країн, яка передбачає:

- повагу прав людини, включаючи трудові права міжнародних мігрантів;

- створення гідних можливостей для роботи в країнах походження, зробивши міграцію свідомим вибором, а не вимушеною необхідністю;

- забезпечення справедливого набору та рівного ставлення до робітників-мігрантів з метою запобігання експлуатації та рівних умов щодо громадян;

— формування механізму "справедливої міграції" у процесах регіональної економічної інтеграції;

- сприяння двостороннім угодам про регулювання трудової міграції між державами;

- сприяння соціальному діалогу шляхом залучення міністерств праці, профспілок та організацій роботодавців до фрормування політики в сфрері трудової міграції;

- сприяння зміцненню багатостороннього порядку денного стосовно питань трудової міграції.

Нарешті, зміна клімату та деградація навколишнього середовища можуть спричинити кліматичну міграцію робочої сили, оскільки сільське господарство чи рибальство стають нежиттєздатними, або тому що підвищення рівня моря може змусити цілі групи населення тікати зі своєї країни.

Складність міжнародної трудової міграції та мобільності, включаючи потоки біженців, далі зростає. Багато країн недостатньо підготовлені для вирішення цієї ситуації, яка внаслідок поганого функціонування ринку праці та слабкого управління призводить до нерегульованої міграції, недостатнього використання навичок, невідповідності робочих місць, дискримінації, збільшення нерівності, в тому числі при прийомі на роботу. Відсутність регулювання трудової міграції може посилити дефіцит гідної роботи для робітників-мігрантів та їх сімей, а також призвести до довгострокових несприятливих соціальноекономічних витрат для країн походження та призначення. Чи буде корисна міграція робочої сили або ні, дуже залежить від політичної бази країн походження та призначення, а також від двостороннього, регіонального та багатостороннього співробітництва між ними.

\section{Література:}

1. Гуменюк Ю.П. Міжнародна трудова міграція: методологічний та організаційний аспекти: монографія / Ю.П. Гуменюк. - Тернопіль: ТНЕУ, 2013. 619 с.

2. Садова У.Я. Міграція в умовах трансформації регіональних ринків праці України: механізми регулювання / ДУ "Інститут регіональних досліджень імені М.І. Долішнього НАН України"; наук. ред. Львів, 2019. - 263 с. (Сер. "Проблеми регіонального розвитку").

3. Sardak S., Korneyev M., Dzhyndzhoian V., Fedotova T., Tryfonova O. "Current trends in global demographic processes", 2018. Problems and Perspectives in Management. Vol. 16 (1), pp. 48-57. DOl: http://dx.doi.org/ 10.21511/ppm.16 (1).05.

4. World Migration Report 2020 https://www.un.org/en/development/desa/population/migration/ publications/migrationreport/docs/InternationalMigration 2020_Report.pdf
5. International Migration Report UN DESA, 2019a. Datasets available at www.un.org/en/development/ desa/population/migration/data/estimates2/ estimates19.asp

6. Глобальний портал даних про міграцію http:// migrationdataportal.org

7. International Labor Organization (2018b) Supporting resilient labor markets to drive inclusive economic growth and decent work for all - Summary of emerging lessons learned from ILO Syrian crisis interventions in Jordan, Turkey and Lebanon 2013-2017, Geneva, http:/ /www.ilo.org/wcmsp5/groups/public/-ed_protect/protrav/-migrant/documents/genericdocument/ wcms_613633.pdf

8. ILO Global Estimates on International Migrant Workers. Results and Methodology. Second edition (reference year 2017) https://www.ilo.org/wcmsp5/ groups/public/dgreports/dcomm/publ/documents / publication/wcms_652001.pdf

\section{References:}

1. Gumeniuk, Y.P. (2013), Mizhnarodna trudova migratsiia: metodologichnuy ta organizatsiynuy aspect [Mizhnarodna trudova migratsiia: metodologichnuy ta organizatsiynuy aspect], TNEU, Ternopil, Ukraine.

2. Sadova, U. (2019), Migratsiia v umovah transformatsii regionalnyh rynkiv pratsi Ukrainu: mehanizmy reguliyvannia [Migratsiia $v$ umovah transformatsii regionalnyh rynkiv pratsi Ukrainu:mehanizmy reguliyvannia], DU Institut regonalnyh doslidzhen imeni M.I. Dolishnogo NAN Ukrainu, Lviv, Ukraine.

3. Sardak, S. Korneyev, M. Dzhyndzhoian, V. Fedotova, T. and Tryfonova, O. (2018), "Current trends in global demographic processes", Problems and Perspectives in Management, vol. 16 (1), pp. 48-57.

4. The official site of United Nations (2020), "World Migration Report 2020", availableat:https://www.un.org/en/development/desa / population/migration / publications/migrationreport/docs (Accessed 20 October 2020).

5. The official site of United Nations (2019), "International Migration Report UN DESA,2019", available at: www.un.org/en/development/desa/population / migration / data /estimates2 (Accessed 20 October 2020).

6 . The official site of Global Migration Data Portal (2020), available at: http://migrationdataportal.org (Accessed 22 October 2020).

7. The official site of International Labor Organization (2018), "Supporting resilient labor markets to drive inclusive economic growth and decent work for all Summary of emerging lessons learned from ILO Syrian crisis interventions in Jordan, Turkey and Lebanon 20132017", available at: http://www.ilo.org/wcmsp5/ groups/public/ed_protect/protrav/migrant/documents /genericdocument (Accessed 24 October 2020).

8. The official site of International Labor Organization (2017), "ILO Global Estimates on International Migrant Workers. Results and Methodology. Second edition", available at: https://www.ilo.org/wcmsp5/groups / public/dgreports/dcomm/publ/documents (Accessed 25 October 2020).

Стаття надійшла до редакиї 03.11.2020 p. 